\title{
WEWENANG PELAKSANAAN DISKRESI KEPOLISIAN DALAM UPAYA PENEGAKAN HUKUM (TINJAUAN DARI PERSPEKTIF YURIDIS NORMATIF)
}

\section{WAYAN WISADNYA,SH MH}

Fakultas Hukum Universitas Mahendradatta Denpasar, Jalan Ken Arok Nomor 12 Denpasar,

\author{
(wisadnyarena@gmail.com)
}

\begin{abstract}
ABSTRAK, Permasalahan mengenai Law infoscment ( penegakan hukum ) khususnya di dalam Diskresi kepolisian, hal ini bukan sekedar hanya sebuah pilihan bagi polisi, namun merupakan bagian penting dan tidak dapat dihindarkan dalam melakukan tugas penegakan hukum, dengan tujuan untuk menekan angka kriminalitas, demi terciptanya situasi yang aman dan tertib ditengah-tengah masyarakat serta kondisi yang kondusif. Dalam buku Black Law Dictionary berasal dari bahasa belanda Discretionair Yang berarti Kebijaksanaan dalam hal memutuskan suatu tindakan tidak berdasarkan ketentuan-ketentuan peraturan,undang-undang atau hukum yang berlaku, tetapi atas dasar kebijaksanaan, pertimbangan atau keadilan. Kewenangan Polri dalam pelaksanaan diskresi kepolisian dalam upaya penegakan hukum dilakukan dengan cara bertindak demi kepentingan umum berdasarkan penilaian sendiri dan hanya dalam keadaan yang sangat perlu, dengan memperhatikan Perundang-undangan, Seperti UU No 2 Tahun 2002 Tentang Kepolisian Negara Republik Idonesia, Kitab Undang-Undang Hukum Acara Pidana ( KUHAP ) dan Perkap NO 1 Tahun 2009 , selain itu juga harus menjunjung tinggi HAM serta Kode etik Profesi Kepolisian. Oleh karena itu, dapat di identifikasi permasalahan dilapangan adalah : apakah yang menjadi kewenangan Kepolisian dalam pelaksanaan diskresi ? serta bagaimanakah upaya penegakan hukum ?, selanjutnya kajian ini menggunakan metode pendekatan yuridis Normatif yaitu pendekatan berdasarkan Peraturan perundang-undangan, serta bahan-bahan hukum yang berlaku sebagai hukum Positif di Indonesia . Jadi kesimpulannya adalah kewenangan polri dalam pelaksanaan diskresi kepolisian dalam upaya penegakan hukum dilakukan dengan cara bertindak sendiri demi kepentingan umum berdasarkan penilaian sendiri dan hanya dalam keadaan yang sangat mendesak dengan memperhatikan peraturan perundang-undangan, seperti UU Kepolisian, KUHAP dan Perkap( Praturan Kapolri No 1 Tahun 2009), serta Menjunjung tinggi HAM dan Kode Etik Profesi Kepolisian Negara Republik Indonesia.
\end{abstract}

Kata kunci : Wewenang, Pelaksanaan Diskresi, Kepolisian, Penegakan hukum.

\section{PENDAHULUAN}

Suatu Tranding topik yang tidak
akan habis-habisnya dibahas dalam
kehidupan masyarakat, adalah sebuah
phenomena pelanggaran dan kejahatan(
criminal), phenomena ini, selalu dapat dikaji

secara yuidis normative maupun yuridis emperik. Yang mana kompleks tindakan pelanggaran dan kejahatan dimaksud secara tidak langsung dapat dilihat dari berbagai aspek, seperti diantaranya mulai dari pelanggaran hingga kejahatan, seperti 
penganiayaan,pencurian, perampokan, bahkan masih banyak kejahatan-kejahatan lainnya yang merugikan masyarakat

Dengan kondisi yang demikian, tentunya itu merupakan masalah yang harus segera mungkin untuk ditangani, mengingat masalah tersebut sangat erat kaitanny adengan situasi kamtibmas yang harus terjaga dan dipelihara. Sehingga untuk mewujudkan hal tersebut sudah tentu Negara memiliki peran dan tanggung jawab, yang mana peran dan tanggungjawab tersebut dilakukan melalui Lembaga/ institusi Kepolisian dengan tujuan terciptanya suasana Kamtibmas. Secara umum Kamtibmas sendiri pada hakekatnya merupakan rangkaian upaya pemeliharaan ketertiban umum ( maintaining law and order ), Penanggulangan kejahatan (fighting crime) dan Perlindungan warga (protecting people ) terhadap kejahatan ( crime) dan Bencana ( disaster)

Di dalam fungsi kepolisian menjaga keamanan dan ketertiban masyarakat, tentu hal itu harus didukung juga dengan otoritas hukum. salah satunya adalah peraturan kepala kepolisian Negara Republik Indonesia Nomor 7 tahun 2009 Tentang sistem Laporan gangguan keamanan dan ketertiban masyarakat ( selanjutnta disingkat Perkap No 7 Tahun 2009.

Berangkat dari hal tersebut diatas, Kepolisian Daerah Bali melakukan berbagai upaya melalui DIT SAMAPTA POLDA Bali dengan tujuan untuk menekan angka kriminalitas demi terciptanya situasi yang aman dan tertib ditengah-tengah masyarakat yang sering disebut Kamtibmas. Oleh karna sebagai alat Negara, LembagaKepolisian diberikan kewenangan dan kendali penuh dalam rangka penegakan hukum yang nantinya dapat memcapai tujuan dimaksud salah satu dengan diberikannya Kewenangan diskresi kepolisian. Membahas Mengenai penegakan hukum, diskresi polisi sejatinya bukan hanya sekedar sebuah pilihan bagi polisi, namun merupakan bagian penting dan tidak dapat di hindarkan dalam melakukan penegakan hukum. Dalam kaitannya tentu penegakan hukum itu sendiri merupakan suatu proses yang hakekatnya sebagian dari penerapan diskresi yang menyangkut pembuatan suatu keputusan yang tidak secara ketat terikat oleh kaedah-kaedah hukum dan melibatkan usaha manusia. Akan tetapi , dalam hal pelaksanaannya dilapangan tentu yang harus diperhatikan ialah bagaimana batasan dari wewenang diskresi dimaksud, sehingga nantinya tidak 
menimbulkan suatu polemic /perdebatan sosial mengingat pemahaman akan tugas dan fungsi kepolisian atas tindakan diskresi masih cukup minim ditengah-tengah masyarakat, apa lagi masih ada beberapa oknum kepolisian yang juga melakukan penyalah gunaan diskresi yang berakibat kerugian bagi masyarakat itu sendiri. Oleh karena itu dapat Di identifikasi permasalahannya adalah : apakah yang menjadi kewenangan diskresi Kepolisian dalam pelaksanaan upaya penegakan hukum. ? selajutnya dalam penulisan ini akan mempergunakan methode pendekatan yaitu methode pendekatan Yuridis Normatif ( berdasarkan peraturan Perundang-undangan yang berlaku sebagai hukum positif di Indonesia saat ini.

\section{PEMBAHASAN}

\subsection{Dasar Hukum Wewenang Diskresi Oleh Kepolisian}

Pembahasan mengenai diskresi tentunya menyangkut tentang pengambilan keputusan yang tidak sangat terikat oleh hukum, dimana penilaian pribadi juga memegang peranan. Diskresi diartikan sebagai kebebasan mengambil keputusan dalam setiap situasi yang dihadapi. Diskresi selalu di kaitkan dengan pengambilan keputusan,kekuasaan, atau kewenangan yang dilakukan seseorang terhadap persoalan yang dihadapinya. Sementara itu diskresi kepolisian merupakan suatu wewenang menyangkut pengambilan suatu keputusan pada kondisi tertentu atas dasar pertimbangan dan keyakinan pribadi seorang kepolisian. 1). ( Susanto.F Anton : 2004 : 12 ). Secara umum pelaksanaan diskresi merupakan yang lumrah dan dilaksanakan sejak dulu oleh para pengambil keputusan karena diskresi tidak dapat dihindarkan dalam penegakan hukum disebabkan dua alasan yaitu :

1. Penerapan aturan dalam kasus yang sederhana dalam kenyataan pasti membutuhkan sifat bijaksana dari seorang petugas. Suatu perbuatan pidana dapat diterapkan aturan yang sama namun dilain kondisi tidak bias karena alasan yang ada pada saat itu. Aturan pada prinsipnya diterapkan secara subyektif oleh penegaknya. Kemampuan subyek pelaksanaan bervariasi tergantung tanggapannya terhadap tindakan pelanggaran yang terjadi. Sebagai contoh : dalam suatu perbuatan yang dianggap melanggar akan dianggap pemaksaan kehendak oleh seorang petugas tapi pada petugas 
lain akan mempertimbangkan factor apakah pelaku membela haknya atau karena terpaksa atau kelalaian atau kesengajaan karena kesembronoan dan lain-lain yang tidak sama dengan petugas pertama dalam memberikan pertimbangan.

2. Eksistensi, Kepentingan dan Penerapan diskresi memberi kesan bahwa penegakan hukum tidak memberikan batasan untuk menyelidiki dan meneliti bila memang ditemukan. Penegakan hukum tetap dijamin bagi masyarakat luas dan bukan ditentukan oleh satu atau individu saja.2) ( Kemal Dermawan, $2015: 102$ ).

Adanya diskresi kepolisian tentu tidak terlepas dari tugas polri, dimana tugas dimaksud sebagai penjaga kemanan dan ketertiban masyarakat yang diantaranya melaksanakan pengaturan penjagaan, pengawalan , dan patroli terhadap kegiatan masyarakat dan pemerintah sesuai kebutuhan ; menyelenggarakan kegiatan dalam menjamin keamanan,ketertiban dan kelancaran lalu lintas di jalan; membina masyarakat untuk meningkatkan partisipasi masyarakat, kesadaran hukum masyarakat, serta ketaatan warga masyarakat terhadap hukum dan peraturan perundang-undangan, sehingga akan mempermudah kepolisian dalam menjalankan tugas dan fungsinya. Akan tetapi dalam pelaksanaan Diskresi tersebut memiliki beberapa ketetentuan yang menjadi dasar hukum sebagai legitimasi yang nantinya menjadi sebuah pedoman batasan atas tindakan diskresi yang dilakukan oleh kepolisian, sehingga dengan demikian semua pihak terlindungi baik tugas polisi itu sendiri maupun masyarakat. Suatu tindakan diskresi diperlukan dalam pelaksanaan tugas polri dimungkinkan karena :

a. Tidak ada peraturan perundangundangan yang sedemikian lengkapnya sehingga dapat mengatur semua prilaku manusia.

b. Adanya keterlambatan untuk menyesuaikan perundangundangan dengan perkembangan didalam masyarakat, sehingga menimbulkan ketidak pastian. 
c. Kurangnya biaya untuk menerapkan perundang-undangan sebagaimana yang dikehendaki oleh Pembentuk undang- undang. 3) ( Soerjono soekanto, $1983: 12$ ).

Adapun beberapa perundangundangan yang dapat di jadikan dasar hukum pelaksanaan diskresi itu khususnya dalam upaya penegakan hukum antara lain sebagai berikut :

1. Menurut Undang-undang Dasar Negara R I Tahun 1945 : Dalam pembukaan Undangundang Dasar 1945 ;Bertitik tolak dari pikiran melindungi segenap Bangsa Indonesia, Pasal $27 \quad$ UUD,1945 memerikan kesamaan kedudukan di dalam hukum dan pemerintahan pada setiap warga negaranya. Dan kekedudukan polisi selaku penegak hukum wajib melindungi warga negaranya dan menciptakan keamanan dan ketertiban bagi masyarakat.
2. Menurut Undang-Undang Nomor 2 Tahun 2002 Tentang Kepolisian Negara Republik Indonesia.

Berkaitan dengan
wewenang diskresi yang
dimiliki kepolisian, tetntu
tidak terlepas dari tugas da
fungsi pokok Kepolisian. Hal
tersebut dikarenakan tugas dan
fungsi kepolisian memiliki
makna yang cukup luas jika
dijabarkan berdasarkan UU
Nomor 2 Thun 2002 Tentang
Kepolisin Negara Republik Indonesia, yang menyebutkan bahwa pemeliharaan keamanan dalam negeri melalui upaya penyelenggaraan fungsi kepolisian meliputi pemeliharaan keamanan dan ketertiban masyarakat,penegakan hukum, perlindungan , pengayoman, dan pelayanan masyarakat dilakukan oleh kepolisian Negara Republik Indonesia selaku alat Negara yang dibantu oleh masyarakat dengan menjunjung tinggi hak 
azasi manusia,sehingga

diperlukan kewenangan dalam

menjalankan tugas dan fungsi

tersebut.

Diskresi kepolisian merupakan tindakan yang dibenarkan oleh Undangundang Kepolisian sebagai manadiatur dalam pasal 16 (1) huruf 1, dan pasal 18 (1) dan (2) UU Kepolisian Nomor 2 Tahun 2002.

Dalam pasal 16 ayat (1) huruf 1 :

Kepolisian Negara Republik Indonesia Berwenang untuk mengadakan tindakan lain menurut hukum yang bertanggung jawab.

Dalam pasal 18 ayat (1) dan (2) :

( 1). Untuk kepentingan umum pejabat Kepolisian Negara Republik Indonesia dalam melaksanakan tugas dan wewenangnya dapat bertidak memurut penilaiannya sendiri.

(2). Melaksanakan ketentuan sebagaimana dimaksud dalam ayat (1) hanya melakukan dalam keadaan yang sangat perlu dengan memperhatikan peraturan per-undangundangan, serta kode etik profesi kepolisian Negara Republik Indonesia.

Dalam penjelasan pasal 18 ayat (1) UU No 2 Tahun 2002 menyebutkan bahwa yang dimaksud dengan Bertindak Menurut Penilaiannya sendiri" adalah suatu tindakan yang dapat dilakukan oleh anggota kepolisian Republik Indonesia.

Polisi Republik Indonesia dalam menjalankan tugas dan wewenang khusus dalam melakukan diskresi tidak boleh bertentangan dengan peraturan Perundang-undangan, namun jika prbuatan diskresi yang diambil lebih bermanfaat dan menguntungkan kepentingan umum, maka peraturan perundang-undangan tersebut dapat di kesampingkan. 
3. Menurut Kitab UndangUndang Hukum Acara Pidana ( KUHAP).

Diatur dalam ketentuan pasal 5 dan pasal 7 UU Nomor 8 Tahun 1981 disebutkan bahwa setiap pejabat kepolisian yang berkwalifikasi menyelidik dan menyidik dalam rangka melaksanakan tugas dibidang pradilan pidana karena kewajibannya diberi wewenang oleh Undangundang. Mengingat wewenang Kepolisian untuk melakukan tindakan-tindakan kepolisian tidak mungkin diatur secara terperinci, maka dalam ketentuan pasal 5 ayat (1) angka 4 dan pasal 7 ayat (1) huruf $\mathrm{j}$ dinyatakan bahwa polisi berwenang karena kewajiban melakukan tindakan lain menurut hukum yang bertanggung jawab.

Berdasarkan pasal 7ayat (1) tersebut polisi dapat mengambil tindakan lain pada saat penyidikan selain yang telah disebutkan pada aturan per-undang-undangan tersebut. selama ini demi kepentingan tugas-tugas

kepolisian,sekelipun polisi telah diberikan kewenangan oleh UU untuk mengambil tindakan lain tersebut tetap saja polisi harus bisa untuk mempertanggung jawabkan atas segala tindakan dan keputusan yang telah diambil didalam melaksanakan tugasnya.

4. Menurut Peraturan Kapolri ( Perkap ) No 1 Tahun 2009 Tentang : Penggunaan Kekuatan Dalam Tindakan Kepolisian.

Tujuannya adalah untuk memberikan pedoman bagi anggota Polri dalam pelaksanaan tindakan kepolisian yang memerlukan penggunaan kekuatan, sehingga terhindar dari penggunaan kekuatan yang berlebihan atau tidak dapat dipertanggungjawabkan.Sedan gkan dalam pasal 2 ditentukan bahwa tujuan penggunaan 
kekuatan dalam tindakan

kepolisian adalah :

a. Memcegah,menghambat,at au menghentikan pelaku kejahatan atau tersangka yang sedang berupaya atau sedang melakkan tindakan yang bertentangan dengan hukum.

b. Mencegah pelaku kejahatan atau tersangka melarikan diri atau melakukan tindakan yang membahayakan anggota Polri atau masyarakat.

c. Melindungi diri atau masyarakat dari ancaman perbuatan atau perbuatan pelaku kejahatan atau tersangka yang dapat menimbulkan luka parah atau mematikan, atau

d. Melindungi kehormatan kesusilaan atau harta benda diri sendiri atau masyarakat dari serangan yang melawan hak dan / atau mengancam jiwa manusia.
Pasal 3 Peraturan Kepala Kepolisian Negara Republik Indonesia No 1 Tahun 2009 Tentang Penggunaan Kekuatan

Dalam Tindakan Kepolisian juga menyebutkan Prinsipprinsip Penggunaan Kekuatan sebagai batas dalam tindakan Kepolisian ( diskresi ) adalah :

1. Legalitas, yang berati bahwa semua tindakan kepolisian harus sesuai dengan hukum yang berlaku.

2. Nesesitas, yang berarti bahwa penggunaan kekuatan dapat dilakukan bila memang diperlukan dan tidak dapat dihindarkan berdasarkan situasi yang dihadapi.

3. Proporsionalitas, yang berarti bahwa penggunaan kekuatan harus dilaksanakan secara seimbang antara 


$$
\begin{aligned}
& \text { ancaman yang di } \\
& \text { hadapi dan tingkat } \\
& \text { kekuatan atau respon } \\
& \text { anggota polri, sehingga } \\
& \text { tidak menimbulkan } \\
& \text { kerugian/korban/ } \\
& \text { penderitaan yang } \\
& \text { berlebihan. }
\end{aligned}
$$

4. Kewajiban umum, yang berarti bahwa anggota Polri diberikan kewenangan untuk bertindak atau tidak bertindak menurut penilaian sendiri,untuk menjaga,memelihara ketertiban dan menjamin keselamatan umum.

5. Preventif, yang berarti bahwa tindakan kepolisian mengutamakan penncegahan.

$\begin{array}{ll}\text { 6. Masuk akal } & \text { (Reasonebel) yang }\end{array}$ berarti bahwa tindakan kepolisian diambil dengan mempertimbangkan

secara logis situasi kondisi dari ancaman ataau perlawanan pelaku kejahatan terhadap petugas atau bahaya terhadap masyarakat.

\subsection{Wewenang Pelaksanaan Diskresi Oleh Kepolisian Dalam Upaya Penegakan Hukum}

Dalam menjalankan
tugasnya polisi $\quad$ senantiasa
memperhatikan keserasian antara
masalah ketertiban dan keamanan
masyarakat. Didalam ketertiban
masyarakat ada suatu sistem norma
dan prilaku.Norma-norma yang
hidup dan berlaku ditengah
masyrakat antara lain , Norma
kesuliaan, Norma sopan santun,
norma kepercayaan, norma
hukum.Sistem norma tersebut
sebaiknya dipahami $\quad$ oleh
setiappetugas polisi Karena tatanan
norma itu merupakan bagian dari
kehidupan masyaakat dimana
petugas polisi yang bersangkutan
ditempatkan. Pelaksanaan diskrsi
yang benar dan cocok dengan


norma-norma yang ada dalamm masyarakat akan menimbulkan sikap yang simpati kepada polisi.

Adapun Faktor-faktor yang mempengaruhi pelaksanaan diskresi dalam tugas polisi Antara lain :

\section{Faktor Pendidikan}

Salah satu hal yang mempengaruhi diskresi kepolisian adalah factor pendidikan dari anggota kepolisian yang bersangkutan yang mana dalam hal ini mata pelajaran yang diproleh dari pendidikan ( sekolah) kepolisian merupakan bekal dasar dalam pelaksanaan tugas polisi. Bekal dasar tersebut selanjutnya dikembangkan dan diwarnai dengan pengalaman-pengalaman praktek petugas. Adapun masalahmasalah yang dihadapi polisi dilapangan ada yang bersifat biasa dan luar biasa, sehingga latihanlatihan praktek semu ( pura-pura ) dalam pendidikan sekolah polisi tidak hanya diajarkan latihan mengahdapi masalah-masalah konvensional, tetapi juga mencakup latihan dalam menghadapi masalah inkonvensional.

2. Faktor Pengalaman

Pengambilan kebijakan polisi dalam diskresi dipengaruhi oleh pengalaman dari anggota kepolisian yang bersangkutan. Pengalaman-pengalaman bertugas dilapangan yang cukup lama akan mempengaruhi keluwesan pengambilan kebijakan polisi dalam menghadapi pelanggaranpelanggaran yang dilakukan oleh warga masyarakat tertentu. Hal tersebut pada dasarnya karena pengalaman dapat mempengaruhi cara berpikir dan bertindak seorang petugas polisi dilapangan.

\section{Faktor Mental}

Kesulitan-kesulitan hidup yang dialami oleh seorang anggota polisi yang bertugas dikota besar, dapat mempengaruhi keseimbangan kepribadian seseorang yang tidak kuat mentalnya. Pola hidup konsumtif di kota besar dan berkembang teentunya dapat mempengaruhi kehidupan seseorang yang mempunyai mental di luar nalar, 
misalnya menerima uang suap ( melakukan pungli ) untuk mengatasi sesuatu kebutuhan rumah tangganya. Dalam hal ini dapat terjadi kebijakan diskresi ditukar dengan imbalan uang dengan jumlah tertentu.

4. Faktor Sikap Prilaku Pelanggar Hukum

Seseorang yang telah melakukan pelanggaran ( misalnya melanggar ketentuan rambu-rambu lalu lintas) dan tertangkap petugas, jika menampilkan sikap prilaku yang sopan dan mengaku bersalah serta mengemukakan alasan-alasannya kenapa ia melanggar dengan logis, dan minta maaf, dapat dimungkinkan petugas yang bersangkutan memberi kebijakan diskresi, membebaskan si pelanggar lalu lintas tersebut. Jika pelanggaran itu ringan sifatnya, mungkin si petugas akan memberi nasihat-nasihat / peringatan terhadap si pelanggar.

Selain itu, Berdsarkan pada pasal 18 Undang-Undang No 2 Tahun 2002 yaitu : Untuk kepentingan umum, Pejabat Kepolisian Negara

Republik Indoesia dalam
melaksanakan tugas dan
wewenangnya dapat bertindak
menurut Penilaiannya sendiri”
Fungsi Kepolisian telah dijelaskan
dalam pasal 2 UU No: 2 Tahun
2002 Tentang Kepolisian Negara
Republik Indonesia yang berbunyi
"Fungsi Kepolisian adalah salah
satu fungsi pemerintahan dibidang
keamanan dan ketertiban
masyarakat serta penegakan
hukum, Perlindungan,
$\begin{aligned} & \text { Pengayoman, dan pelayanan } \\ & \text { kepada masyarakat”. }\end{aligned}$

\subsection{Wewenang Kepolisian dalam} Pelaksanaan Diskresi

Berkaitan denan wewenang pelaksanaan deskresi oleh kepolisian, diskresi kepolisian sering diartikan sama dengan penyampingan perkara. Keadaan sebenarnya tidaklah sepenuhnya benar sama seperti demikian. Hal ini dapat dimaklumi mengingat cakupan tugas polisi tidak hanya terbatas dalam penanganan perkara, melainan juga meliputi tugas pencegahan dalam rangka pemeliharaan keamanan,ketertiban dan dalam rangka 
memberikan perlindungan, pengayoman serta pelayanan terhadap masyarakat. Dari Tinjauan aspek organisasi, maka untuk melaksanakan tugas pokok kepolisian, institusi memiliki ciri-ciri sebagai berikut :

1. Memiliki kekuasaan kepolisian ( Police Power ) yang bersumber pada pemberian wewenang kepolisian berdasarkan undang-undang yang lingkupnya dapat membatasi hak-hak konstitusional warga masyarakat.

2. Pelaksanaan tugas kepolisian dengan menggunakan pendekatan oprasional yang melibatkan seluruh anggota dalam pelaksanaan tugas oprasional.

Mengingat luasnya cakupan tugas dan fungsi kepolisian yang tidak hanya terbatas pada penegakan hukum, melainkan meliputi tugas-tugas dalam rangka memelihara keamanan masyarakat. Tentu keadaan seperti ini menuntut diterapkan adanya suatu kebijaksanaan bertindak atas pertimbangan pribadi petugas Polri yang bersangkutan yang dikenal dengan istilah diskresi. Diskresi tersebut perlu diterapkan dengan dasar sebagai berikut

a. Tidak ada peraturan perundangundangan yang dapat mengatur seluruh tingkah laku manusia.

b. Tidak ada praturan perundangundangan yang isinya betul-betul jelas bagi warga masyarakat yang diaturnya ( misalnya dari segi bahasa,isi dan juga pembentukannya).

c. Yang diatur adalah manusia yang mempunyai perbedaanperbedaan, misalnya mentalitas ,latar belakang kebudayaan pendidikan,motivasi untuk berprilaku tertentu, seperti misalnya potensinya untuk menyimpang dan menyeleweng,serta seterusnya.

d. Sulit sekali untuk menyerasikan kebutuhan untuk menerapkan Peraturan Perundang-undangan dengan fasilitas yang mendukungnya. 4) ( Aryanto Sutadi Dkk, 2013 :47)

Wewenang kebijaksanaan pengambilan keputusan yang diambil oleh petugas polisi tersebut harus berada dalam ruang lingkup 
kewajibannya yaitu kewajiban polisi untuk menciptakan situasi ketertiban dan keamanan dalam msyarakat .Kebijakan keputusan yang diambil ini dapat berarti pula bahwa perkara ringan tersebut tidak diproses terus, karena pelanggaran itu bersifat ringan ( tidak diajukan kesidang pengadilan ). Karena diskresi kepolisian terletak diantara garis batas moral dan humu, maka untuk mencegah agar tidak terjadi tindakan penyalah gunaan wewenang perlu dibatasi pelaksanaannya dengan azas kewajiban.

Azas Kewajiban terdiri dari 4 ( empat) Sub azas, yang merupakan dasar patokan bagi pelaksana diskresi, Yaitu

\section{Azas Keperluan:}

Azas keperluan adalah azas yang memberi pedoman bahwa tindakan polisi hanya dapat dilakukan apabila tindakan itu benar diperlukan untuk meniadakan suatu gangguan atau mencegah terjadinya suatu gangguan.

2. Azas Masalah :

Azas masalah adalah merupakan suatu patokan, memberi pedoman bahwa tindakan yang dilakukan oleh polisi harus selalu dikaitkan dengan permasalahannya, dan tindakan polisi tidak boleh mempunyai motif pribadi.

3. Azas Tujuan :

Azas Tujuan, menghendaki agar tindakan polisi betul-betul tepat dan mencapai sasarannya, guna menghilangkan atau mencegah terjadinya suatu gangguan yang merugikan.

4. Azas Keseimbangan :

Azas Keseimbangan memberi pedoman kepada petusas polisi agar tindakan Polisi selalu seimbang antara keras dan lunak tindakan yang diambil, seimbang antara alat yang digunakan dengan ancaman yang dipakai.

\section{Disamping itu juga,} terdapat tindakan atau penerapan diskresi keplisian yang tidak dapat dituntut didepan hukum diatur di dalam pasal 18 UU Kepolisian Negara Reppublik Indonesia ( UU No 2 Tahun 2002 ). Dan didalam pasal 7 
KUHAP ( Kitab Undang-

undang hukum acara Pidana

), Namun tentunya

kewenangan ini dapat

dilakukan

dengan

pertimbangan

tertentu

sebagai batasan-batasan.

Tindakan Polisi dibatasi oleh

1. Azas Keperluan, bahwa tindakan itu harus benarbenar diperlukan.

2. Tindakan yang diambil benar-benar untuk kepentingan tugas kepolisian.

3. Azas Tujuan, bahwa tindakan yang paling tepat untuk meniadakan suatu gangguan atau tidak terjadinya suatu kekhawatiran terhadap akibat yang lebih besar.

4. Azas Keseimbangan, bahwa dalam mengambil tindakan harus diperhitungkan keseimbangan antara sifat tindakan atau sasaran yang digunakan dengan besar kecilnya gangguan atau berat ringannya suatu obyek yang harus di tindak . 5). ( Soerjono Soekanto, $1986: 12$ ).

Ketentuan dalam pasal 18 Undangundang No 2 Tahun 2002 Tentang Kepolisian Negara Republik Indonesia di Jelaskan bahwa :

1. Untuk Kepentingan umum Pejabat Kepolisian Negara Republik

Indonesia,dalam

melaksakan tugas dan wewenangnya dapat bertindak menurut penilaiannya sendiri.

2. Pelaksanaan ketentan sebagaimana dimaksud dalam ayat (1) hanya dapat dilakukan dalam keadaan yang sangat perlu dengan memperhatikan 
peraturan per-undangundangan, serta kode etik Profesi

Kepolisian Negara

Republik Indonesia

Kalimat dalam pasal 18 tersebut yang berbunyi “ bertindak Menurut penilaian sendiri" merujuk konsep diskresi atau "Freies Ermessen" Dalam bahasa Inggris, diskresi ( discretion ) mengandung arti "the quality of being discreet, or careful about what one does and says"

Dari kalimat tersebut mempunyai makna yakni kualitas yang bijaksana, atau berhatihati tentang apa yang dilakukan dan dikatakan. Jadi, makna kata diskresi yang telah dijelaskan diatas yakni harus dilakukan dengan penuh kehati-hatian.

Selanjutnya dalam UU No 2 Tahun 2002 tersebut diskresi dirumuskan sebagai dalam keadaan yang sangat perlu, penjelasan resmi dari UU tersebut berbunyi yang dimaksud dengan bertindak menurut penilaiannya sendiri” adalah suatu tindakan yang dapat dilakukan oleh anggota Kepolisian Negara Republik Indonesia yang dalam bertindak harus mempertimbangkan manfaat serta resiko dari tindakannya dan betul-betul untuk kepentingan umum.6)( Rahardjo satjipto, $2010: 103$ )

Permasalahan penerapan diskresi oleh kepolisian dapat diatasi secara perlahan-lahan . salah satu caranya adalah dengan memperhatikan serta mematuhi batas-batas dalam melaksanakan tugas dan wewenang petugas kepolisian tersebut. Diskresi yang diberikan kepada petugas dalam kepolisian juga mengenal batas-batas tertentu yang harus diperhatikandan tidak boleh disimpangi karena penyimpangan dari azas diskresi akan melahirkan penyalah gunaan wewenang dan kesewenangwenangan. Hal demikian tentu saja akan berdampak buruk kepada masyarakat. Maka dari itu, ketika petugas kepolisian akan menggunakan diskresi untuk melakukan tindakan bagi keadaan yang mendesak, polsi harus benar-benar memahami pembatasan dalam pengambilan tindakan tersebut. Menurut Warsito Hadi Utomo, Sistem pertanggung jawaban atas kesalahan ataupun kelalaian yang dilakukan oleh anggota Polri adalah sebagai berikut :

1. Pelanggaran dari norma hukum pidana harus dipertanggungjawabkan menurut hukum pidana. 
2. Apabila ia merugikan orang lain dalam melaksanakan tugas atau perintah jabatan yang sah, maka negaralah yang bertanggung jawab, sehingga setiap orang yang dirugikan dapat menuntut ganti rugi dari Negara berdasarkan suatu inrechtmatige overheidsdaad melalui Pradilan Tata Usaha Negara.7 )( Warsito Hadi Utomo, $2005: 20$ )

Dari rumusan rumusan tersebut diatas dapat diambil kesimpulan bahwa tindakan seeorang petugas kepolisian dianggap tidak sah, tidak hanya apabila :

a. Melanggar hukum baik yang berlaku umum ( misalnya melanggar Undang-undang Hukum Pidana ) maupun yang berlaku khusus ( misalnya melakukan pemeriksaan kendaraan dijalan umum walaupun ada larangan dan dinas ).

b. Tanpa dasar hukum baik berupa tindakan tanpa hak dan wewenang ( misalnya memaksa seseorang membayar hutangnya) maupun tindakan melampaui batas-batas wewenang ( misalnya memukul dan menganiaya tersangka)

c. Mempunyai pertimbanganpertimbangan diluar persoalan ( Misalnya mengulur-ulur pemeriksaan tersangka bukan karena kurang alat bukti, tetapi karena sikap tersangka kurang sopan);

d. Ingin mencapai tujuan lain ( misalnya menahan surat ijin mengemudi sipelanggar lalu lintas agar dapat uang tebusa 8.( Ibid : 21)

Oleh karena itu, meskipun tujuan dan maksud dilakukannya diskresi kepolisian sangat abstrak dan dapat mengundang bermacam-macam penafsiran yang berbeda, sepatutnya dapat dipertanggung jawabkan dari segi hukum,segi moral,maupun etika kepolisian. Diskresi kepolisian sangat rentan penyimpangan dan penyalah gunaan sehingga perlu diberikan 
batasan dan pengawasan. 9. (

Pudi Rahardi, 2007 : 29 )

Menurut Roeslan Saleh, suatu tindakan penyalah gunaan kekuasaan harus dipertanggung jawabkan dan kena hukum sesuai dengan sistem hukum atau norma yang dilanggar itu.10 ( Roeslan Saleh, 1984 : 34 )

\subsection{Batasan Wewenang Kepolisian} dalam Pelaksanaan Diskresi.

$$
\begin{aligned}
& \text { Berkaitan } \\
& \text { dengan } \\
& \text { kewenangan kepolisian } \\
& \text { dalampelaksanaan diskresi ,tentu } \\
& \text { tidak dirumuskan batas batasannya, } \\
& \text { unsur dan kreterianya, sehingga } \\
& \text { penggunaan diskresi kepolisian ini } \\
& \text { rentan adanya tindakan penyalah } \\
& \text { gunaan wewenang dan tindakan } \\
& \text { sewenang wenang. Hal ini dapat } \\
& \text { disebabkan dengan bentuk-bentuk } \\
& \text { penyimpangan atau pengembangan } \\
& \text { diskresi yang beragam, namun } \\
& \text { dapat diklompokan sebagai berikut }
\end{aligned}
$$

untuk memproleh keuntungan pribadi. Unsur kesengajaan penyalah kegunaan wewenang dengan dalih suatu kebijakan merupakan ciri dari penyimpangan tindakan diskresi yang dierapkan.

2. Miss Function, salah dalam peneraopan atau dalam pelaksanaan diskresi. Hal ini disebabkan karena berbagai keterbatasan pada penerap diskresi itu sendiri yang meliputi ketidak tahuan akan adanya suatu ketentuan atau peraturan hukum, kurang ketrampilan, kurang pengalaman tanpa adanya unsur kesengajaan untuk melakukan kesalahan itu, apalagi kehendak untuk menyalahgunaan kewenangan.

3. Non Functio, yaitu bertindak pada waktu 


$$
\begin{aligned}
& \text { melihat suatu peristiwa } \\
& \text { yang sebenarnya } \\
& \text { memerlukan tindakan } \\
& \text { polisi. Adapun contoh } \\
& \text { dari tindakan keputusan } \\
& \text { atau kebijaksanaannya } \\
& \text { untuk bertindak seperti } \\
& \text { seorang anggota } \\
& \text { kepolisian yang melihat } \\
& \text { suatu kejadian kecelakaan } \\
& \text { lalu lintas untuk } \\
& \text { mengambil keputusn } \\
& \text { dengan melakukan } \\
& \text { pembiaran tanpa } \\
& \text { pengambil tindakan } \\
& \text { apapun, bahkan anggota } \\
& \text { kepolisian dengan } \\
& \text { sengaja meningalkan } \\
& \text { tempat tersebut.11.( } \\
& \text { Aryanto Sutadi, } 2013 \text { : } \\
& \text { 112) }
\end{aligned}
$$

Jadi dengan dimikian ada beberapa hal yang memberikan kewenangan, dan serta batasan batasan dalam menjalan menjalankan tindakan diskresi oleh anggota kepolisian.

\section{III . PENUTUP}

\section{Kesimpulan}

Berdasarkan hasil penelitian dan pembahasan , maka dapat diambil kesimpulan : Bahwa Kewenangan Polri dalam pelaksanaan diskresi kepolisian dalam upaya penegakan hukum dilakukan dengan cara bertindak demi kepentingan umum berdasarkan penilaian sendiri dan hanya dalamkeadaan yang sangat perlu dengan memperhatikan peraturan -perundang-undangan, seperti : UU RI : No 2 Tahun 2002 Tentang Kepolisian Negara Republik Indonesia, UURI No 8 Tahun 1981 ( KUHAP ) Serta Peraturan Kapolri ( Perkap ) No 1 Tahun 2009 Tentang Penggunaan Kekuatan Dalam Tindakan Kepolisian. Disamping itu aparat kepolisian juga harus menjunjung tinggi hak azasi manusia, serta kode etik profesi kepolisian Republik Indonesia, sebagai suatu hal yang fundamental dan penting, dan besar pengaruhnya terhadap baik buruknya pelaksanaan diskresi oleh Kepolisian.

\section{Saran}

Bahwa berkaitan dengan wewenang pelaksanaan diskresi yang dilakukan kepolisian, tentu sangat perlu adanya 
pemahaman-pemahaman yang terkait dengan tugas pokok dan fungsi ( Tupoksi ) kepolisian sebagai bekal bagi setiap anggota kepolisian dalam melaksanakan tugas Negara, baik dari segi ketrampilan, pengalaman, mentalitas, serta kemampuan, dalam memahami batasan wewenang diskresi kepolisian. Hal tersebut dirasa sangat penting untuk menghindari terjadinya tindakan penyalah gunaan wewenang atau kelalaian dalam melaksanakan tugas khusunya dalam melakukan diskresi yang dapat merugikan masyarakat luas.

\section{DAFTAR- BACAAN}

\section{A. Buku-Buku}

Aryanto sutadi,DKK, 2013 Kepolisian dalam tinjauan Hukum Dan

Implementasinya dilapangan, Jakarta, Komisi

Kepolisian Nasional.

Kemal Dermawan, 2015, Sosiologi

Peradilan Pidana, Jakarta, Buku Obor, Markas Besar

Indonesia

Kepolisian Negara Republik

Lembaga Pendidikan, Pedoman Pelaksanaan

Tugas Brigadir Polisi di Lapangan.

Rahardjo satjipto, 2010, Sosiologi Hukum, Genta publishing, Yogakarta

Roeslan Saleh, 1984 ,Pikiran pikiran tentang pertanggung jawaban pidana .Jakarta, Ghalia Indonesia.

Soejono Soekanto, 1983, Faktor-Faktor Yang Mempengaruhi Penegakan
Hukum ,Jakarta, PT Raja Grafindo

Persada.

Susanto F. Anton, 2004, Kepolisian Dalam

Upaya Penegakan Hukum di

Indonesia, Jakarta, Renika Cipta.

Wasito Hadi Utomo, 2005, Hukum

Kepolisian di Indonesia, Jakarta

Prestasi Jakarta.

\section{B. Per-Undang-undangan}

1. Undang-undang Dasar Negara Republik Indonesia Tahun 1945.

2. Undang-Undang Republik Indonesia Nomor 2 Tahun 2002 Tentang Kepolisian Negara Republik Indonesia.( Lembaran Negara RI No 2 Tahun 2002.

3. Undang-Undang Republik Indonesia No : 8 Tahun 1981 Tentang KUHAP Kitab Undang-undang Hukum Acara Pidana( Lembaran Negara Tahun 1981 No 76, Tambahan Lembaran Negara No 3209)

4. Undang-Undang Republik Indonesia No 1 Tahun 1946 Tentang Kitab Undang-Undang Hukum Pidana ( KUHP )

5. Peraturan Kepala Kepolisian Republik Indonesia No 21 Tahun 2007 Tentang Bimbingan Penyuluhan Keamanan dan Ketertiban Masyarakat.

6. Peraturan Kepala Kepolisian Republik Indonesia No 7 Tahun 2009 Tentang Sistem Laporan Gangguan Keamanan Dan Ketertiban Masyarakat.

7. Peraturan Kepala Kepolisian Republik Indonesia ( Perkap ) No : 1 Tahun 2009 Tentang Penggunaan Kekuatan Dalam Tindakan Kepolisian. 
